\title{
Biometric and Physiological Responses to Water Restriction in Moringa oleifera Seedlings
}

\author{
Michelle Conceição Vasconcelos ${ }^{1}$ (D), Joel Conceição Costa ${ }^{1}$ (D), \\ João Paulo Silva Sousa ${ }^{2}$ (D), Fernanda Vieira Santana ${ }^{3}$ (D), \\ Tássia Fernanda Santos Neri Soares ${ }^{4}$ (D), \\ Luiz Fernando Ganassali de Oliveira Júnior ${ }^{1}$ (D), Renata Silva-Mann ${ }^{1}$

\begin{abstract}
${ }^{1}$ Departamento de Engenharia Agronômica, Universidade Federal de Sergipe - UFS, São Cristóvão/SE, Brasil ${ }^{2}$ Departamento de Engenharia Agronômica, Faculdade do Nordeste da Bahia - FANEB, João Sá/BA, Brasil ${ }^{3}$ Programa de Pós-graduação em Agricultura e Biodiversidade, Universidade Federal de Sergipe - UFS, São Cristóvão/SE, Brasil

${ }^{4}$ Departamento de Fitotecnia, Universidade Federal de Viçosa - UFV, Viçosa/MG, Brasil
\end{abstract}

\begin{abstract}
A water deficit in the soil can cause water stress in plants, triggering morphological and physiological changes. The aim of this work was evaluate the ecophysiological development of moringa seedlings under controlled water restriction. The experimental design was completely randomized at $40,60,80$, and $100 \%$ of field capacity and six replicates. The photosynthetic $\mathrm{CO}_{2}$ assimilation, stomatal conductance, transpiration, vapor pressure deficit, internal carbon concentration, chlorophyll $a$, chlorophyll $b$, and total chlorophyll and stem diameter, height, and number of leaves were measured at 9 a.m. during 21 days of restriction. The treatments differed for photosynthetic parameters. Moringa seedlings reduce gas exchange to adapt to water restrictions until $40 \%$ of field capacity. The alterations promoted by water restriction did not negatively affected plant development.
\end{abstract}

Keywords: Moringaceae, stress, gas exchange, moringa. 


\section{INTRODUCTION}

Under tropical conditions, agricultural yield can be negatively affected by a number of biotic and abiotic stresses that alter plant growth and development. In this context, nutrient deficiencies, such as nitrogen and phosphorus limitations, and stresses caused by low water availability and high temperatures have been frequently highlighted (Silva et al., 2012a).

A water deficit is one of the most severe and common types of abiotic stress that affects crops grown in semiarid environments. The effect is evident at any plant growth stage and may vary according to the severity and duration of the stress (Farooq et al., 2009).

A water deficit in the soil can cause water stress in plants, triggering morphological and physiological changes. Low water availability can elicit reductions in cellular expansion, leaf area, the root to shoot biomass ratio, and photosynthesis and can promote stomatal closure and increased leaf abscission (Taiz \& Zeiger, 2009). When plants are exposed to a water deficit, they frequently exhibit physiological responses that indirectly result in water conservation in the soil, as if the plants were saving the water for a later time period (Souza \& Lima, 2012).

Plants require large water and nutrients quantities throughout their life cycle, and all aspects of plant development are affected by low soil moisture content. Low soil moisture content causes changes in the physical environment at soil, which subsequently affect physiological and biochemical processes at plant (Sarker et al., 2005).

In a study of the species Gethyllis multifolia and Gethyllis villosa, which grow in semiarid southern Africa, G. multifolia was suggested to be more sensitive to water than G. villosa, and both species adopted specific morphological changes in their leaves under shade conditions. During drought stress, compared with G. multifolia, G. villosa exhibited an increased photosynthetic performance that appeared to be unrelated to leaf adaptations, and G. villosa leaves maintained their stomatal conductance $\left(g_{s}\right)$, photosynthetic light compensation (LCP), and photon fields at greater levels (Daniels et al., 2013).

Several species have been studied to observe their behavior under water restriction at some stage of development, initial or adult, such as Jatropha curcas (Padilha et al., 2016), Campomanesia adamantium (Dresch et al., 2016), Eucalyptus urograndis (Costa et al., 2015), Tabebuia aurea (Cabral et al., 2004), Guazuma ulmifolia (Scalon et al., 2011), Schizolobium amazonicum [S. parahyba var. amazonicum], and Schizolobium parahyba [Schizolobium parahybum] (Carvalho, 2005).

Several parameters have been assessed to evaluate the response of plant species to water restrictions, including leaf water potential, osmotic potential and relative water content, stomatal conductance and transpiration, leaf temperature, and proline accumulation. However, studies of this nature have not been conducted for moringa, which has high potential for planting under semiarid conditions.

Thus, an ecophysiological study of moringa during its early growth stage is extremely important, mainly by helping to establish ecophysiological parameters indicative of tolerance to abiotic stress. When these parameters are well managed, they can improve seedling production and establishment and thus facilitate the selection of genetic material resistant to stressful edaphoclimatic conditions.

Moringa (Moringa oleifera) is a Indian fast growing species that has a good development in the Brazilian semi-arid that requires little care regarding forest management. It is a species that presents several uses, from lubricant to medicine, and most used parts of the plant are the seeds, because it is rich in oil, and the leaves are rich in nutrients for use in human and animal food.

Thus, this study aimed to evaluate the ecophysiological (photosynthetic $\mathrm{CO}_{2}$ assimilation, stomatal conductance, transpiration, vapor pressure deficit between the leaf and the air, internal carbon concentration, chlorophyll $a$, chlorophyll $b$, and total chlorophyll) and biometric (stem diameter, height, and number of leaves) development of $M$. oleifera seedlings subjected to controlled water restriction.

\section{MATERIALS AND METHODS}

The experiment was performed at the Federal University of Sergipe campus (Campus da Universidade Federal de Sergipe - UFS), located in the municipality of São Cristóvão, state of Sergipe (SE), Brazil, geographical 
coordinates $19^{\circ} 59^{\prime} 24.3^{\prime \prime} \mathrm{S} 37^{\circ} 05^{\prime} 59.3^{\prime \prime} \mathrm{W}$, in the period from January to March 2013. During the experimental period, the environmental conditions inside of the greenhouse, represented by the mean temperature and mean relative humidity of the air, as measured daily with a thermohygrometer, were $35.7 \pm 3^{\circ} \mathrm{C}$ and $51 \pm 6.5 \%$, respectively.

Seedlings of a single genotype (matrix) grown from seeds that had been harvested in the municipality of Aracaju were used. The seedlings were cultivated in $13 \mathrm{~L}$ polypropylene pots and maintained in a greenhouse under natural light. The substrate was composed of washed sand, clay, and cattle manure in a 1:1:1 ratio. The substrate (in the pots) was maintained at field capacity for 50 days, and then a 21-day period of water restriction was imposed. The pots containing the plants were weighed on a balance (precise to three decimal places) daily, always at the same time, to determine the quantity of water consumed, and then a corresponding volume of water was added to the pot to maintain the water capacity of each treatment.

The experiment was conducted in a completely randomized design with four treatments (40,60, 80, and 100\% field capacity) and six replicates. Each plot consisted of $13 \mathrm{~L}$ pot with one plant. In order to determine soil water capacity, the pots were saturated in a box with water volume equivalent to two thirds of pot height during $24 \mathrm{~h}$. The box was covered with plastic film to avoid evaporation and placed to drain freely, being measured their masses after 24 h (Casaroli \& Van Lier, 2008).

Gas exchange was measured on fully expanded mature leaves, with average value of three leaflets per plant, located in the middle third of each plant using an IRGA infrared gas analyzer (model LI-6400xt, LI-color Nebraska, USA) with an air flow of $300 \mathrm{~mL} \mathrm{~min}^{-1}$ and a coupled light source of $1,500 \mu \mathrm{mol} \mathrm{m}^{-2} \mathrm{~s}^{-1}$. The measurements were collected at 9 a.m. The following gas exchange data were obtained: photosynthetic $\mathrm{CO}_{2}$ assimilation $(A)$, stomatal conductance $\left(g_{s}\right)$, transpiration $(E)$, vapor pressure deficit between the leaf and the air $\left(\mathrm{VPD}_{\text {leaf-air }}\right)$, and internal carbon concentration $\left(C_{i}\right)$.

A non-destructive method was used to determine the chlorophyll $a$, chlorophyll $b$, and total chlorophyll, using a ClorofiLOG (Falker) meter that can obtain instantaneous readings of the relative chlorophyll in a leaf. The measurements were collected from fully expanded mature leaves, with average value of three leaflets per plant, from the middle third of each plant at the same time interval as the other analyses.

The biometric parameters were measured in all of plants every weekly during the 21 days of water restriction. The total height was measured for the stem of each plant using a centimeter tape measure. The stem diameter was measured at approximately $10 \mathrm{~cm}$ from the soil using a digital caliper. The leaf number was determined by counting the expanded leaves on each plant. The fresh and dry masses of the shoots and of the root systems were determined at the end of the experiment. The shoots were separated from the root system (the roots were washed and dried in the shade to remove excess substrate), weighed, and dried in a forced-circulation oven at $60^{\circ} \mathrm{C}$ to a constant weight to obtain the dry mass.

The data were subjected to analysis of variance, evaluating the significance of the $\mathrm{F}$ test at the 5\% probability level and regression analysis using the SISVAR' program (Ferreira, 2008).

\section{RESULTS}

The ecophysiological parameters (photosynthetic $\mathrm{CO}_{2}$ assimilation, stomatal conductance, internal carbon concentration, transpiration, and vapor pressure deficit between the leaf and the air) of the moringa seedlings differed significantly among water restriction treatments.

With an increase in water restriction, the photosynthetic $\mathrm{CO}_{2}$ assimilation rate, internal carbon concentration and transpiration all decreased (Figure 1).

In contrast to the gas exchange results, the chlorophyll $a$, chlorophyll $b$, and total chlorophyll levels of the moringa seedlings did not differ significantly among water restriction levels $(p>0.05)$ (Figure 2). However, chlorophyll $a$ was present at approximately three-fold higher levels in the plants than chlorophyll $b$.

Similar to the chlorophyll results, the evaluated biometric parameters of the moringa seedlings also did not differ significantly ( $p>0.05)$ among water restriction treatments (Figure 3 ). 

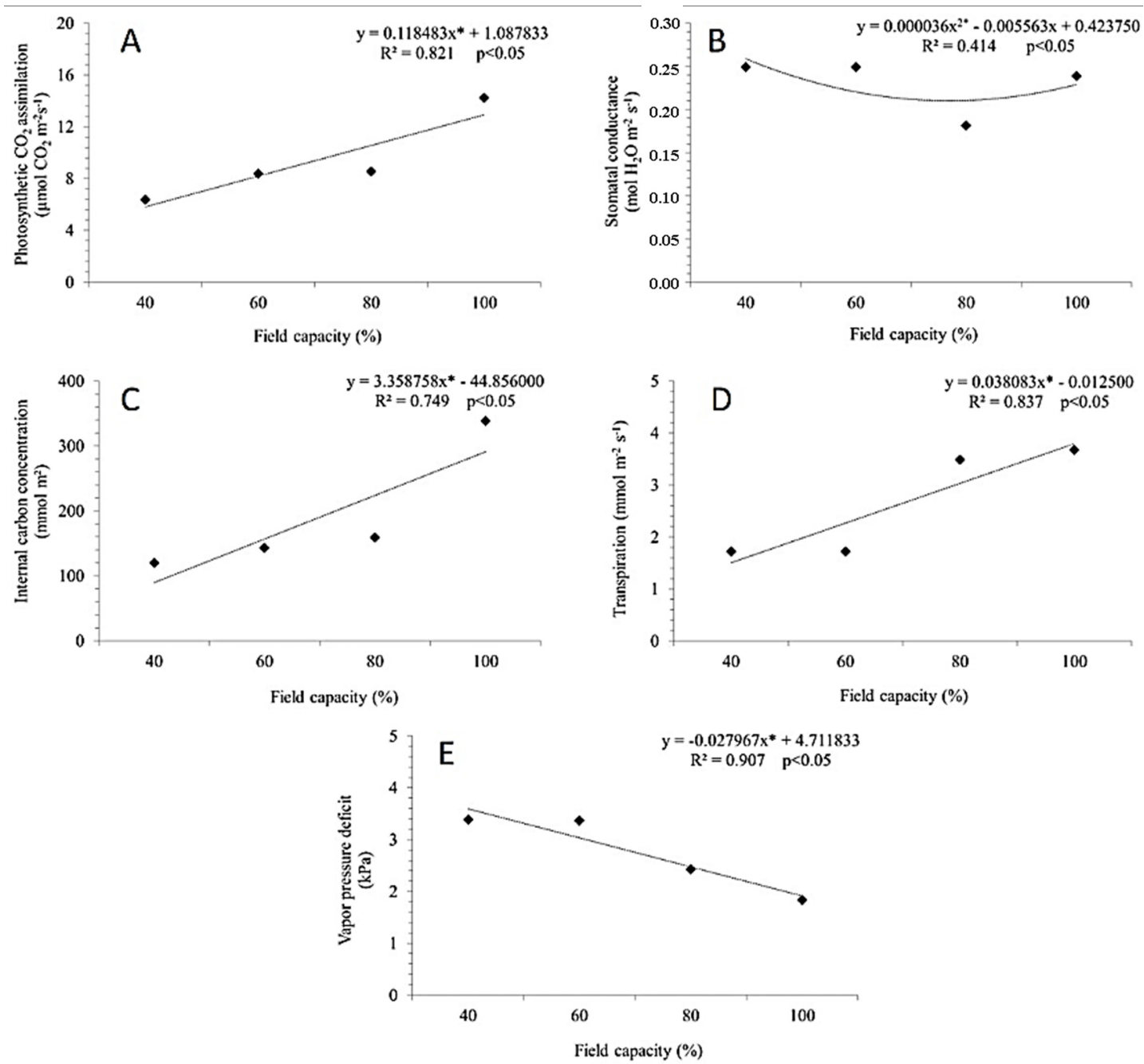

Figure 1. Photosynthetic $\mathrm{CO}_{2}$ assimilation (A), stomatal conductance (B), internal carbon concentration (C), transpiration (D), and vapor pressure deficit between the leaf and the air (E) of Moringa oleifera Lam. seedlings subjected to water restrictions.



Field capacity $(\%)$

- Chla $\quad$ Chlb $\quad$ Chlt $\quad$ Chala $/ \mathrm{b}$

Figure 2. Chlorophyll $a(\mathrm{Chl} a)$, chlorophyll $b(\mathrm{Chl} b)$, total chlorophyll (Chl T), and the ratio of $\mathrm{Chl} a / b$ of Moringa oleifera Lam. seedlings subjected to water restrictions. 

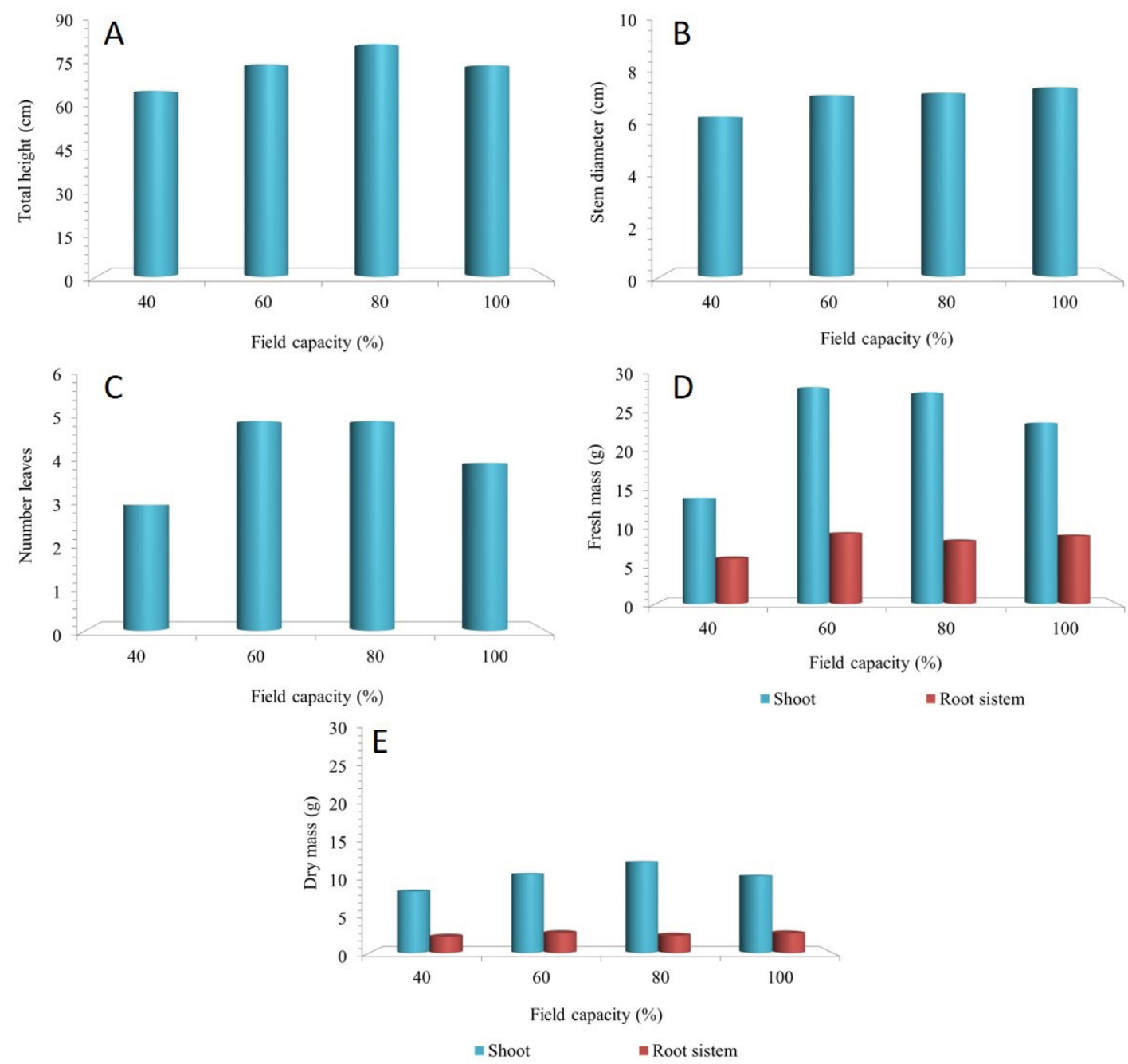

Figure 3. Total height (A), stem diameter (B), number of leaves (C), fresh mass (D), and dry mass (E) of Moringa oleifera Lam. seedlings subjected to water restrictions.

\section{DISCUSSION}

The ecophysiological and biometric parameters of moringa were analyzed to evaluate the effects of the intensity of the stress caused by water deficit on the photosynthetic apparatus of moringa seedlings subjected to controlled water restriction. The water deficits did not cause severe damage to the moringa seedlings; there was no change in stomatal conductance compared to extreme levels of restriction, which constitutes one of the first strategies employed by plants to reduce transpiration and to maintain turgor pressure (Eckstein \& Robinson, 1996).
The ecophysiological parameters (photosynthetic $\mathrm{CO}_{2}$ assimilation, internal carbon concentration, transpiration, and vapor pressure deficit between the leaf and the air) decreased with an increase in the severity of the water restriction. Water deficit normally leads to a decrease in the photosynthetic rate, although tolerance levels may vary for different plant species (Scalon et al., 2011).

Similar results for photosynthetic $\mathrm{CO}_{2}$ assimilation, stomatal conductance, and transpiration were reported by Rivas et al. (2013), who subjected 50-day-old M. oleifera plants to two stress cycles (the first lasted 10 days and the second lasted 8 days), subjecting 
plants to $10 \%$ of the pot field capacity and rehydration between the stress cycles.

Stress usually increases the diffusive resistance to water vapor by triggering stomatal closure, reducing transpiration and, consequently, the supply of $\mathrm{CO}_{2}$ for photosynthesis (Nogueira et al., 1998). However, what happened to the transpiration of moringa seedlings was the same found for some species of the Caatinga, in which the reduction in transpiration values in some species gave to the availability of water in the soil than by stomatal closure (Silva et al., 2004); for example, when plants are subject to drought cycles, they can develop specific responses to low water availability that allow for the maintenance of transpiration for longer periods under these conditions (Larcher, 2006).

Another factor that corroborates the claim that the seedlings did not undergo severe damage as a result of exposure to water restrictions is that the chlorophyll levels remained constant during the restriction period. Moreover, it was maintained with a ratio of chlorophyll $a$ and $b$ of 3:1, suggesting that, in terms of the chlorophyll levels, the plants were exposed to normal conditions (Taiz \& Zeiger, 2009). Chlorophylls are a group of photosynthetic pigments present in the chloroplasts of plants that are responsible for capturing solar radiation to transmit energy and they impart the green color to plants (Marenco \& Lopes, 2005). Deficiencies in chlorophyll are recognizable by the presence of a pale color, or chlorotic leaf, and are associated with considerably reduced photosynthetic rates (Larcher, 2006).

When subjected to salt stresses of 0,75 , and $150 \mathrm{mM}$ of $\mathrm{NaCl}$, the photosynthetic pigments of 30-day-old moringa plants also did not differ significantly among treatments, but did contain higher levels after treatment with a higher saline concentration (Silva et al., 2012b).

Similar gas exchange results have been reported for umbu plants (Spondias tuberosa) in the dry season as a mechanism for the plants to adapt for their survival (Lima, 2004). Thus, the moringa seedlings underwent an adaptive process in response to the water deficit in the soil.

Aroeira (Schinus terebinthifolius) is moderately tolerant to low levels of water restriction in the soil, and young aroeira plants perform better when grown with a water supply of $75 \%$ of field capacity and can be grown with water levels as low as $50 \%$ of field capacity without exhibiting any significant morphological or physiological changes (Silva et al., 2008).

The moringa biometric parameters remained stable during the restriction process. According to Taiz \& Zeiger (2009), this happens because many plant physiological processes are affected by water deficit. As plant growth is controlled by cell division, followed by cell expansion, insufficient water maintains cells that growing zones under conditions. Thereby, it reducing cell division coefficient and all cells expansion, thus preventing plants vegetative growth.

Padilha et al. (2016) studied initial jatropha growth under a water restriction regime $(20,40,60,80$ and $100 \%$ of soil water retention capacity). It was obtained because water regimes of 60 and $80 \%$ provide the best responses for physiological and growth variables in the initial phase. However, regimes lower than $60 \%$ and greater than $80 \%$ induce signs of water stress in young jatropha plants.

For C. adamantium, Dresch et al. (2016) observed that low water availability (retention capacities of 25 and 50\%) reduces these plants growth rates and their green and dry biomasses production. The biomass production is limited by stomata closure mechanism and leaf area reduction, since it causes, respectively, a decrease in $\mathrm{CO}_{2}$ fixation and light interception (Silveira et al., 2016).

As moringa has survival strategies under water restriction, mulungu (Erythrina velutina) seedlings have potential to develop xeromorphic characteristics, such as defoliation and greater root development. However, the seedlings production cannot be in water restriction conditions, so it can guarantee its better vegetative development (Oliveira et al., 2016).

Although water stress altered the physiological attributes values, there were no negative effects/reflexes on the plant growth (at levels and time imposed). It indicates they were adapted to reduce plant water losses so it did not impair their development.

A given plant species can overcome adverse environmental conditions, i.e., may exhibit varying performance, which is reflected as plasticity. Thus, physiological evaluations cannot be restricted to a single genotype and must also consider performance under highly diverse water restriction conditions to test for differential plasticity. 
The plants performance observation in the early development stages during stress situations allows better understanding about their survival in natural environments, where condition can be the most adverse as possible without a control intervention.

\section{CONCLUSION}

M. oleifera seedlings have the ability to reduce gas exchange under water restrictions as severe as $40 \%$ of field capacity to adapt to these conditions and maintain their survival. Despite physiological changes promoted by the water deficit, there was no negative effect on plant growth until the level and time of stress imposed.

\section{ACKNOWLEDGEMENTS}

To CNPq, Conselho Nacional de Desenvolvimento Científico e Tecnológico, for granting masters fellowship to Michelle Conceição Vasconcelos.

\section{SUBMISSION STATUS}

Received: 28 oct., 2015

Accepted: 24 jan., 2018

\section{CORRESPONDENCE TO}

\section{Michelle Conceição Vasconcelos}

Departamento de Engenharia Agronômica, Universidade Federal de Sergipe - UFS, Av. Marechal Rondon, s/n, Jardim Rosa Elze, CEP 49100-000, São Cristóvão, SE, Brasil e-mail: michelle_florestal@yahoo.com.br

\section{FINANCIAL SUPPORT}

CNPq (Conselho Nacional de Desenvolvimento Científico e Tecnológico).

\section{REFERENCES}

Cabral EL, Barbosa DDA, Simabukuro EA. Crescimento de plantas jovens de Tabebuia aurea (Manso) Benth. \& Hook. f. ex S. Moore submetidas a estresse hídrico. Acta Botanica Brasílica 2004; 18(2): 241-251. http://dx.doi. org/10.1590/S0102-33062004000200004.
Carvalho CJR. Responses of Schizolobium amazonicum [S. parahyba var. Amazonicum] and Schizolobium parahyba [Schizolobium parahybum] plants to water stress. Revista Árvore 2005; 29(6): 907-914. http://dx.doi.org/10.1590/ S0100-67622005000600009.

Casaroli D, Van Lier QDJ. Critérios para determinação da capacidade de vaso. Revista Brasileira de Ciência do Solo 2008; 32(1): 59-66. http://dx.doi.org/10.1590/S010006832008000100007 .

Costa MDAA, Santos VAHF, Vieira CV, Farias AL No, Menegucci JLP, Zolin CA et al. Aspectos ecofisiológicos e de crescimento de Eucalyptus urograndis submetido à suplementação hídrica em plantios clonais. Revista de Biologia Neotropical 2015; 12(1): 44-57. http://dx.doi. org/10.5216/rbn.v1i1.28306.

Daniels CW, Mabusela WT, Marnewick JL, Valentine AJ. Photosynthetic adaptation of two semi-arid species of Gethyllis (Kukuma kranka) to drought-and-shade stress. South African Journal of Botany 2013; 88: 36-41. http:// dx.doi.org/10.1016/j.sajb.2013.03.018.

Dresch DM, Scalon SPQ, Mussury RM, Kodama FM. Initial growth of Campomanesia adamantium (CAMBESS.) O. Berg. seedlings on substrates with different compositions and water retention capacities. Bioscience Journal 2016; 32(1): 1-10. http://dx.doi.org/10.14393/BJ-v32n1a2016-26121.

Eckstein K, Robinson JC. Physiological responses of banana (Musa AAA; Cavendish sub-group) in the subtropics. VI. Seasonal responses of leaf gas exchange to shortterm water stress. Journal of Horticultural Science 1996; 71(5): 679692. http://dx.doi.org/10.1080/14620316.1996.11515448.

Farooq M, Wahid A, Kobayashi N, Fujita D, Basra SNA. Plant drought stress: effects, mechanisms and management. Agronomy for Sustainable Development 2009; 29(1): 185 212. http://dx.doi.org/10.1051/agro:2008021.

Ferreira DF. SISVAR: um programa para análises e ensino de estatística. Revista Symposium 2008, 6: 36-41.

Larcher W. Ecofisiologia vegetal. São Carlos: Rima Artes; 2006.

Lima JMP Fo. Gas exchange of the umbu tree under semi-arid conditions. Revista Brasileira de Fruticultura 2004; 26(2): 206-208. http://dx.doi.org/10.1590/S010029452004000200006.

Marenco RA, Lopes NF. Fisiologia vegetal: fotossíntese, respiração, relações hídricas e nutrição mineral. Viçosa: Editora UFV; 2005.

Nogueira RJMC, Barbosa DCA, Moraes JAPV. Trocas gasosas e relações hídricas em plantas jovens envasadas de três espécies da caatinga, submetidas a deficiência de água. Phyton. Vicente López 1998; 62(1): 37-46.

Oliveira MKT, Dombroski JLD, Medeiros RDCA, Medeiros AS. Desenvolvimento inicial de Erythrina velutina sob restrição hídrica. Pesquisa Florestal Brasileira 2016; 36(88): 481-488. http://dx.doi.org/10.4336/2016.pfb.36.88.1261. 
Padilha NS, Silva CJ, Pereira SB, Silva JAN, Heid DM, Bottega SP et al. Crescimento inicial do pinhão-manso submetido a diferentes regimes hídricos em latossolo vermelho distrófico. Ciência Florestal 2016; 26(2): 513521. http://dx.doi.org/10.5902/1980509822752.

Rivas R, Oliveira MT, Santos MG. Three cycles of water deficit from seed to young plants of Moringa oleifera woody species improves stress tolerance. Plant Physiology and Biochemistry 2013; 63: 200-208. http://dx.doi.org/10.1016/j. plaphy.2012.11.026. PMid:23274248.

Sarker BC, Hara M, Uemura M. Proline synthesis, physiological responses and biomass yield of eggplants during and after repetitive soil moisture stress. Scientia Horticulturae 2005; 103(4): 387-402. http://dx.doi. org/10.1016/j.scienta.2004.07.010.

Scalon SPQ, Mussury RM, Euzébio VLM, Kodama FM, Kissmann C. Estresse hídrico no metabolismo e crescimento inicial de mudas de mutambo (Guazuma ulmifolia Lam.). Ciência Florestal 2011; 21(4): 655-662. http://dx.doi.org/10.5902/198050984510.

Silva EC, Nogueira RJMC, Azevedo ADA No, Brito JZ, Cabral ED. Aspectos ecofisiológicos de dez espécies em uma área de caatinga no município de Cabaceiras, Paraíba, Brasil. Iheringia 2004; 59(2): 201-205.

Silva ECA, Santos CA, Silva NV, Silva MA, Souza RP, Nogueira RJMC. Determinação de pigmentos fotossintetizantes em mudas de Moringa oleifera Lam. submetida ao estresse salino. In: Anais do IV Encontro Nacional de Moringa; 2012; Campina Grande. São Cristóvão: Universidade Federal de Sergipe; Campina Grande: Instituto Nacional do Semiárido; 2012 b.

Silva HAP, Galisa PS, Oliveira RSS, Vidal MS, Simões-Araújo JL. Expressão gênica induzida por estresses abióticos em nódulos de feijão-caupi. Pesquisa Agropecuária Brasileira 2012a; 47(6): 797-807. http://dx.doi.org/10.1590/S0100204X2012000600010.

Silva MAV, Nogueira RJMC, Oliveira AFM, Santos VF. Resposta estomática e produção de matéria seca em plantas jovens de aroeira submetidas a diferentes regimes hídricos. Revista Árvore 2008; 32(2): 335-344. http://dx.doi. org/10.1590/S0100-67622008000200016.

Silveira PS, Custódio JPC, Silva FDCM, Nascente ACS, Monteiro CL, Matos FS. A ação dos brassinosteróides no crescimento de mudas de pinhão manso sob déficit hídrico. Agri-Environmental Sciences 2016; 2(1): 52-61.

Souza MA, Lima MDB. Índice de área foliar e produtividade do feijoeiro sob estresse hídrico e profundidades de incorporação do adubo. Global Science And Technology 2012; 5(2): 45-55.

Taiz L, Zeiger E. Fisiologia vegetal. 4. ed. Porto Alegre: Artmed; 2009. 